\title{
El rey, a escena. Mirada y lectura de la fiesta en la génesis del efímero moderno ${ }^{1}$
}

\author{
Fernando Bouza Álvarez ${ }^{*}$
}

\begin{abstract}
RESUMEN
ABSTRACT

Los grandes espectáculos cortesanos,

The great court spectacles, like

asi como la etiqueta, el ceremonial etiquette, palace ceremony, and different royal rituals, can be

palaciego y los distintos rituales monárquicos pueden ser considerados expresiones de la particular cultura política que se desarrolló en Europa a

lo largo de la Alta Edad Moderna. El presente trabajo intenta explicar, en primer lugar, cuál era el papel asignado a fiestas y a espectáculos en la declaración de la relación existente entre un rey y su reino; en segundo lugar, cuál fue el proceso del que terminó por surgir un efímero verdaderamente moderno, cuando la generalización de nuevos medios mecánicos, como el grabado, permitieron la difusión a gran escala de la imagen real; $y$, por último, la efectiva rentabilidad propagandistica que cabia considered expressions of a particular political culture which developed in Europe during the early modern period. This chapter seeks to explain, first, what was the role given to festivals and spectacles as statement about the relationship between a king and his realm; secondly, what was the process which finally generated a truly modern efimero, when the spread of new mechanical tecnology, such as print, permitted the diffusion on a grand scale of the royal image; and. Jastly, the efective propagandistic value which these images pleased at the service of royal power.
\end{abstract} obtener de las imágenes puestas al

servicio del poder monárquico.

- Departamento de Historia Moderna. Universidad Complutense de Madrid.

Una primera versión de este texto ha aparecido publicada en portugués bajo el título "Amor parat regna. Memória visual dos atectos na política barroca», apud XAvItR, Ângela Barreto; y 
"Donnez les spectateurs en spectacle; rendezles acteurs eux mêmes».

Jean Jacques Rousseau, Lettre à d'Alembert.

Como si hubiesen retenido algo de la luminosa calidez del fuego, el más bello de los elementos por la levedad de su materia, sutilmente agitada, las escenas de pirotecnia parecen quintaesenciar el espíritu de esos grandes espectáculos visuales en los que las cortes del Renacimiento y del Barroco buscaban verse a sí mismas, reconociéndose, ordenadas y brillantes, en una ardiente agitación ${ }^{2}$. Al igual que esos artificiosos fuegos de fiesta, también los grandes espectáculos de corte se agotaban en sí mismos, en el regocijo ante una realidad que, con todo orden y previsión, se había planeado fastuosa, pero efímera.

Es cosa sabida que los arcos, máquinas, estrados, palenques y demás invenciones que jalonaron el recorrido de las apoteosis monárquicas habían sido fabricados para no durar. Su ligera arquitectura de madera era tan provisional como los papelones pintados que recubrian sus superficies y sobre los que, con más que audacia en el color muchas veces, se habían trazado complejos emblemas que hablaban de amor, concordia, paz, liberalidad o armonía.

Durante mucho tiempo, estos fastos fueron considerados poco más que derroches decorativos nacidos de la imaginación delirante y fatua propia de la época, cuando no eran condenados como lamentables ejemplos de la decadencia insufrible en que se habían sumido las monarquías clásicas. Pompa insolente y lujo asiático son los duros términos que, por ejemplo, les reserva Madame Roland en sus Mémoires:

"Lorsque je me trouvais cette sorte de spectacle que présentait souvent la capitale dans les entrées de la reine ou des princes, dans les actions de grâces après une couche, je rapprochais avec douleur ce luxe asiatique, cette pompe insolente, de la misere et de l'abjection du peuple abruti qui se précipitait sur le passage des idoles ${ }^{3}{ }^{3}$.

Cardim, Pedro (coord.), Festas que se fizeram pelo casamento do Rei D. Afonso VI. Lisboa, Quetzal, 1996, págs. 7-26.

Ctr. FAGIOLO DELL'ARCO, Maurizio, "Quarantore, fuochi d'allegrezza, catafalchi, mascherate e cose simili", apud M. FAGIOLO y S. CARANOINI, L'effimero barocco. Strutture della festa nella Roma del '600. Roma, Bulzoni Editore, 1978, vol. 2, págs. 1-281. 10, ก. 1

Citado por Ozouf, Mona, La fête révolutionnaire. 1789-1799. París, Gallimard, 1976, pág. 
Hoy, sin embargo, estos grandes espectáculos cortesanos, como la etiqueta o el ceremonial palaciegos y los distintos rituales monárquicos, son estudiados como expresiones de una particular cultura política de cuyo indudable calado constitucional no parece dudarse ${ }^{4}$. Pero, aunque ya están lejos los tiempos en los que se los tenía por meras pompas «insolentes», todavía hoy nos desconcierta que la supuesta expresión de los valores constitutivos de una sociedad política se confiase a espectáculos de endebles arquitecturas, pintados papelones y fuegos de artificio. Qué comunidad recurriría, en suma, a un medio tan poco duradero como éste para proclamar la celebración que de si misma hacia.

Hallar la respuesta adecuada para esta pregunta conlleva haberla encontrado para otras tres cuestiones previas: Primero, la del papel de fiestas y espectáculos en la declaración de la relación que existía entre un rey y su reino; en segundo lugar, la del nuevo sentido que de lo efímero visual se había de imponer a lo largo de la Edad Moderna; y, por último, la de la sabia rentabilidad propagandística que se obtuvo de las imágenes puestas al servicio del poder real.

\section{A ESCENA. LA MAJESTAD COMO GESTO Y EL REY COMO ACTOR}

Después de haber visitado la corte romana, como indicaban los cánones de ese tour meridional que debía realizar todo joven de la nobleza, Leopold von Weissenburg se trasladó a Viena, una corte que no era menos fastuosa que la de los pontífices en tiempos del emperador Leopoldo I. En una de sus cartas al Cardenal Savo Millini, de diciembre de 1697 , el viajero rinde cuenta de sus actividades, entre las que destaca la asistencia a los espectáculos de la corte imperial:

" $J$ ' ai demeuré [en Viena] trois semaines et $j$ ' ais vue la Commedie qu' on a fait à la Cour pour les jours de sa Majesté Imperiale. Dans cette Commedie sa Majesté le Roy des Romains [José I] s’ est signalé entre tous les autres ayant fait des merveilles en dançant" 5 .

Cuando terminaba el siglo xvil no era extraordinario ver danzar en Viena a un futuro Emperador, como antes tampoco lo había sido encontrar

\footnotetext{
${ }^{4}$ Cfr., Bak, Janos M., "Coronation Studies -Past, present and future", apud Bak, Janos M. (ed.), Coronations. Medieval and early modern monarchic ritual, University of California Press. Berkeley-Los Ángeles, 1990, págs. 1-15

s Leopold von Weissenburg à Savo Millini, Kromau, 11 de diciembre de 1697, Biblioteca Particular de Bartolomé March Servera [BPBMS]. Madrid, Fondo Millini, 14/6/7 (IV).
} 
que el Rey Cristianisimo de Francia tomaba parte en el carrousel de un torneo en París, que el Monarca Católico de España salía de máscara un domingo de Carnaval en Madrid o que los diplomáticos acreditados en la corte londinense pugnaran por ver actuar a Carlos I Estuardo en mascaradas y otros sucesos teatrales ${ }^{6}$. Singulares caminos había recorrido la majestad real hasta verse animada de esta manera tan particular, hasta darse a sí misma en espectáculo, muchas veces público sobre calles y plazas ante y entre una muchedumbre regocijada por la aparición de las personas reales. Pero, dejemos esto por ahora y sigamos al caballero Leopold en su viaje por Europa.

Tras Roma y Viena, Von Weissenburg llegó a Copenhague, cuya vida de corte en tiempos de Cristian $\mathrm{V}$ también quiso retratar para su lejano corresponsal cardenalicio:

«Du reste, le sejours de Coppenhaghe me plait beaucoup, j'ais été reçue avec bien de benignité de leurs Majestés et de toute la Maison Royale, j'ais l'honneur de manger tous les jours avec leur Majestés. Presentement, la Cour va à Fägersbourg ou nous jouissons du divertissements de la chasse, les soirs l'on passe en jouant ou en dançant pour la naissance du Roy et pour celle de la Reine l'on a fait deux festes tres magnifiques, les soirs l'on dança dans les chambres du Prince Royal, où toutes les Dames et Cavaliers de la premiere qualitée parurent avec une magnificançe extraordinaire. En un mot, je n'aurois jamais cru que les pays du Nort fussent aussi divertissants et agreables que je les ais trouvé"?

También aquí, en estos fríos «Pays du Nort», las fiestas y diversiones ocupaban un importante lugar en la vida de los reyes; hasta podría decirse que, contra lo que hubiera pensado en un principio, Leopold von Wissembourg, conocedor de las sabrosas Roma y Viena, terminó por concederle a la corte de Cristian $V$ de Dinamarca la condición de tal en atención, precisamente, a esos agradables divertissements. $Y$ es que la fiesta y el espectáculo habían acabado por hacerse inseparables de la vida de corte, cuya obligada magnificencia cumplía un papel que superaba con creces el de saciar la mera ociosidad mundana y se adentraba en el campo de lo político.

\footnotetext{
Para Luis XIV, 1662, y Felipe IV, 1623, véase infra en el texto. Sobre la activa participación de Carlos I Estuardo en distintas masks y los incidentes diplomáticos que produjo, véase LOOMIE, Albert J. (ed.), Ceremonies of Charles I. The Note Books of John Finet, Master of Ceremonies, 1628-1641. Fordham University Press, 1987; y Potten, Lois, Secret rites and secret writing. Royalist literature, 1641-1660. Cambridge, Cambridge University Press, 1989, maxime el epigrafe "The royal actor", págs, 165-176 del capítulo "The royal image: Charles I as text".

Leopold von Weissenburg à Savo Millini, Copenhague, 10 de junio de 1698, BPBMS, Fondo Millini, 14/6/7 (IV).
} 
Quedémonos en esta pequeña corte septentrional, aunque daremos un salto desde finales del XVII hasta la primera mitad del XIX, pasando de las cartas de un caballero peregrino de corte en corte a la obra de Sören Kierkegaard. Y es que en muchas de las páginas de éste aún se dejan oír los ecos últimos de la particular forma de interpretar y hacer pública la majestad real que se habia vivido en la Europa del Antiguo Régimen ${ }^{8}$.

Que "quien no pudiera seducir a los hombres no podría salvarlos" es uno de esos pensamientos que a Kierkegaard le gustaba dejar apenas apuntados entre las notas de su Diario Intimo ${ }^{9}$. Algo hay en su seducir para salvar que recuerda ese gran objetivo de enseñar deleitando en el que se resume buena parte de la pedagogía de persuasión característica del Barroco. Por otra parte, la evocación de una, por excelencia, época alegórica no desentonaría con la personalidad del filósofo empeñado en hacer estética de la melancolía y que ocasionalmente llegó a denominarse a sí mismo pensador barroco ${ }^{10}$.

Dicha condición parece revelarse también en varios pasajes de su Diario íntimo en los que Kierkegaard se ocupa detenidamente de las particularidades de la imagen real, bien porque esboce los rasgos principales de un supuesto modelo de apariencia que los monarcas deberian encarnar a la hora de presentarse ante sus súbditos, bien porque deje constancia de los sentimientos que la visión de los soberanos, y su posterior recuerdo, le habian producido a él mismo, siendo niño o ya con la elaborada melancolía del adulto.

La última vez que se entrevistó con Cristian VIII de Dinamarca en Sorgenfrie, después de haberle entregado un ejemplar de su libro Acciones del amor, Kierkegaard sugirió al rey la conducta que deberia observar en público, suponiendo que un monarca tenía que ocultar con todo cuidado sus rasgos personales para aparecer frente a sus súbditos como sólo el rey. "Ante todo - le dijo- no estaría mal que fuera feo; luego habria de ser sordo y ciego o por lo menos fingir que lo es, pues esto simplifica muchas dificultades... El rey ha de cuidar, de vez en cuan-

\footnotetext{
8 Para la comprensión de los cambios acaecidos en los grandes espectáculos públicos al final del Antiguo Régimen resulta fundamental la citada obra de Ozouf, M., La fête révolutionnaire...; y para la definitiva transformación del ritual cívico, cfr. Ryan. Mary, "The American Parade: Representations of the Nineteenth-Century social order», apud. HUNT, Lynn (ed.). The New Cultural History. Berkeley, University of California Press, 1989, págs. 131-153.

KIERKEgARD, Sören, "Del 15 de mayo de 1848 al 2 de enero de 1849", Diario intimo, trad. de la versión italiana por María Angélica Bosco. Barcelona, Planeta, 1993, pág. 240.

10 Adorno, Theodor W., Kierkegaard. Ensayo. Caracas, Monte Ávila, 1971 [Kierkegaard. Konstruktion des Asthetischen, 1933], pág. 106.
} 
do, de hacerse pasar por enfermo; esa participación —concluia- es siempre excitante" ${ }^{11}$.

En estas máscaras que el filósofo aconsejaba encarnar al soberano resuenan indudables voces modernistas, y no sólo porque le exhortara a ser un disimulado malade imaginaire. Se trata, ahora, del eco de aquellos reyes -si no salvíficos, siempre seductores- que, sobre la privilegiada escena que les estaba reservada, desplegaban los gestos y ademanes propios de su majestad como si fueran auténticos actores. Rezan lapidarias las Mémoires de Luis XIV: "Ce qui fait la grandeur et la majesté des rois n'est pas tant le sceptre qu'ils portent que la manière de le porter» ${ }^{12}$.

La consideración del oficio real como una especie de gran representación en la que los monarcas deberían ser capaces de ir cambiando sucesivamente su figuración aparece nítidamente en distintos textos del siglo XVII, como si la necesidad de practicar la disimulación no se hubiese limitado al estricto ámbito de los cortesanos ${ }^{13}$. Por ejemplo, en el tratado español de El Príncipe Instruido, escrito para la educación de Felipe IV por el Duque de Villahermosa, se supone que a cada dominio territorial le correspondería una forma específica de expresar la majestad monárquica; si en España ésta se veía dominada por la severidad, todo lo contrario debía suceder en Portugal y en Francia, donde "han de ser muy tractables y combersables los príncipes" 0 "en Flandes [donde serán] muy humanos y amigos de sus festines y regocijos». En suma, se concluía que «un Príncipe ha de tener la naturaleza de cera, muy dispuesta a acomodarse con los naturales de sus provincias» ${ }^{14}$.

La ductilidad de esas regias naturalezas de cera se haría evidente en su capacidad para transformarse cuando cambiase el escenario en el que se mostraban. Si El Príncipe Instruido hacía hincapié en la pluralidad de majestades que exigía la diversidad de territorios, aunque compartiesen soberano, en las Mémoires sur la Cour de Louis XIV de Giovanni Battista Primi Visconti se expone la práctica teatral que caracterizaba la conducta del Rey Sol, siempre atento al cambio de escenarios. Así, el Conde de San Maiolo apuntó su observación de que uen público, [el rey] aparece pleno de solemnidad y muy distinto de como es en privado. Cuando estoy

\footnotetext{
Diario..., "Del 2 de enero al 7 de septiembre de 1849", págs. 254-255.

Mémoires de Louis XIV écrits par lui-même, composés pour le Grand Dauphin, son fils, et adressés à ce Prince, ed. de J.L.M. de Gain-Montagnac. París, 1806, "Année 1666", pág. 60.

13 Crr. Rosario VILLARI, Elogio della dissimulazione. La lotta politica nel Seicento. Roma-Bari, Laterza, 1987.

14 Real Biblioteca, Madrid [RB], Mss. II-587, c. 1615, fol. 5 v.
} 
en su apartamento con otros cortesanos, me he percatado a menudo de que si se deja abierta la puerta accidentalmente, o bien si va a salir, inmediatamente adopta otra compostura y otra expresión facial, como si fuera a salir a escena» ${ }^{15}$.

Las propias Mémoires de Luis XIV abundan no sólo en la importancia, sino también en la necesidad de estas salidas a escena que los monarcas debían protagonizar, elevando una preciosa teoría del valor político y comunitario que subyacía tras la celebración de espectáculos de corte y demás ceremonias palaciegas ${ }^{16}$. En junio de 1662 , el rey en persona habia participado en un gran carrousel celebrado en Paris y, queriendo explicar al Delfín el "uso legítimo" que podía hacer de fiestas semejantes, apuntó que:

"Un prince et un roi de France peut encore considerer quelque chose de plus dans ces divertissements publics, qui ne sont pas tant les nôtres que ceux de notre cour et de tous nos peuples. II y a des nations où la majesté des rois consiste, pour une grande partie, à ne se point laisser voir, et cela peut avoir ses raisons parmi des esprits accoutumés à la servitude, qu'on ne gouverne que par la crainte et la terreur, mais ce n'est pas le génie de nos Français, et, $d^{\prime}$ aussi loin que nos histoires nous en peuvent instruire, $s^{\prime}$ il y a quelque caractère singulier dans cette monarchie, $c^{\prime}$ est $l^{\prime}$ accès libre et facile des sujets au prince. $C^{\prime}$ est une égalité de justice entre lui et eux, qui les tient pour ainsi dire dans une société douce et honnête, nonobstant la difference presque infine de la naissance, du rang et du pouvoir. Que cette méthode soit pour nous bonne et utile, I' expériénce l' a déjà montré, puisque dans tous les siècles passés il n' est mémoire d' aucun empire d'aussi longue durée que celui-cil' a eté, et qui toutefois ne semble prêt à finir» " ${ }^{1}$.

Sin duda, estas «Réflexions du Carrousel» constituyen un pasaje de extraordinario valor para comprender la función mayestática y el sentido de la visión regia durante la Edad Moderna. De ellas cabria extraer más de una lección ${ }^{18}$.

\footnotetext{
15 Citado por la ed. de Jean Lemoine (París, 1908) en SMITH, David L. Luis XIV. Madrid, Akal, 1994, trad. de C. Leralta, págs. 122-123. El subrayado es nuestro.

16 Cfr. LAZAROWICZ, "Konzelebration oder Kollusion? Über die Feste der Wittelsbacher» apud Buck, August (ed.), Europäische Hotkultur im 16. und 17. Jahrhundert. Vorträge und Referate gehalten anlässlich des Kongresses des Wolfenbütteler Arbeitkreises für Renaissanceforschung und des Internationalen Arbeitkresises für Barockliteratur in der Herzog August Bibiiothek Wolfenbüttel vom 4. bis 8. September 1979. Hamburg. Hauswedell, 1981, vol. 2, págs. 301-317, maxime el epígrafe "Fest und Theater. Oder über die Differenz zwischen mysticher Partizipation und theatraler Kommunikation".

7 Cito por la edición de Charles Dreyss, Mémoires de Louis XIV pour 1 instruction du Dauphin, 2 vols. Paris, 1860, II, "Appendice II. 1662", pág. 567.

18 Cfr. Burke, Peter, The fabrication of Louis XIV. New Haven, Yale University Press, 1992.
} 
En primer lugar, demuestran la existencia de una conciencia, clara y manifiesta, de que existían distintas tradiciones y maneras de expresar la majestad, desde ésa en la que los reyes no se dejaban ver -clara alusión a la Realeza Oculta elaborada por la Monarquía Hispánica en Castilla - a la mucho más abierta - tratable o conversable, en expresión de El Príncipe Instruido- que se practicaría en Francia y que se fundamentaba, precisamente, en la facilidad con la que las figuras reales se mostraban.

En segundo lugar, se da entender que, en el fondo, cada patrón de majestad estaría en correspondencia íntima con formas también distintas de entender la relación entre los reyes y sus reinos, dejando claro que una de esas brillantes fiestas de corte era algo más que un mero instrumento de adoctrinamiento y propaganda regios. Esto, por supuesto, no invalida los frutos que al poder real le reportaba tan particular «méthode» de salidas a escena y es en las mismas Mémoires donde podemos leer que por medio de esas diversiones ofrecidas al pueblo «nous tenons leur esprit et leur coeur, quelquefois plus fortement peut-être que par les récompenses et les bienfaits" ${ }^{19}$.

En realidad, dichos espectáculos eran, ante todo, entendidos como un manifiesto de la esencial realidad de un reino, una especie de epifanía en la que la comunidad podía contemplarse a sí misma en toda su cohaerentia social y política, manteniendo su estricta jerarquía estamental, pero, al mismo tiempo, exaltando su unidad. Además, la gran fiesta de corte era una de las raras ocasiones en las que era posible reunir al rey, los cortesanos y al pueblo entero, pues el espectáculo pertenecía a todos ellos y todos ellos le daban vida.

Las fiestas ofrecian el escenario idóneo para expresar los valores constitutivos de la comunidad política que, más que sobre la fuerza o la violencia, giraban teóricamente en torno al amor, la armonia, la liberalidad, la alegría, la confianza y la paz que resultaban propios de una «société douce et honnête", como rezan las Mémoires de Luis XIV. La sentencia "Amor parat Regna» que Francisco de Santo Agostinho de Macedo desarrolla en su aristotélica lectio "Amicitia tuetur Regna. Inimicitia evertit» ${ }^{20}$ es una buena síntesis de esa manera de entender la comunidad presidida por la liberalidad de los afectos, en la que el amor concilia a los reinos, la

\footnotetext{
Mémoires..., ed. de Ch. Dreyss, H, pág. 568.

MACEDO, Francisco de Santo Agostinho de, Myrothecium Morale documentorum tredecim quae sunt totidem Lectiones super textum Aristotelis lib. 8 Ethicorum De Amicitia, Patavii, 1675. lectio decima. Véase también la lectio nona, "De amicitia inter Reges \& subiectos".
} 
amistad los protege y la enemistad los subvierte ${ }^{21}$. Sólo triunfará aquel rey que ame a sus súbditos, advierte el antiguo jesuita Macedo, equivocándose penosamente cuantos mantengan a sus súbditos en temor y no en amor $^{22}$.

La clamorosa participación en estos alegres festejos de una multitud de personas de toda condición está, por supuesto, bien probada en las relaciones y otros testimonios en los que se ha dejado noticia de su celebración. La movilización general de una ciudad en la que iba a entrar un nuevo rey era, por ejemplo, recreada retóricamente por Michel de I' Hôpital en una de sus cartas escritas con ocasión del regreso del Duque de Guisa después de haber tomado Calais en 1558:

"Prenez des couronnes, marchez en ordre de fêtes, ô citoyens, accourez comme à l' entrée des Rois nouveaux. Magistrats, venez avec vos faisceaux; suivez, Ministres des Autels; paroissez ensuite troupe inférieure, Conseillers, Chevaliers. Que le Barreau se ferme aujourd'hui, qu' aucun attelier ne soit ouvert, que tous les lieux de la ville honorent le vainqueur» ${ }^{23}$.

El portugués António de Sousa de Macedo quiere transmitir idéntica impresión de participación general cuando describe los términos de un triunfo clásico ${ }^{24}$ :

"O dia de testa solennissima. Ninguem trabalhava. Adornávase a Cidade, ruas, portas \& janelas, o mais ricamente que era possivel, com panos de seda, \& ouro, \& com ramos de flores. Vsávase de toda a sorte de cheiros. A nobreza se vestía de gala; os populares de suas melhores roupas. Os templos estavão abertos ornados com a maior pompa. Tudo mostrava alegría. Deputavãose muitos ministros com varas, \& bastoens para accomodarem a gente pellas ruas, evitando embaraço. Por ellas an-

Sobre esta matriz explicativa vista desde la perspectiva de la historiografía actual, véase la obra fundamental de HESPANHA. António Manuel, La gracia del derecho. Economía de la cultura en la Edad Moderna. Madrid, Centro de Estudios Constitucionales, 1993. Asimismo, resulta sugerente la obra de DEWALO, Jonathan, Aristocratic experience and the origins of modern culture. France, 1570-1715. Berkeley, University of California Press, 1993, maxime el capitulo "Friendship, love and civility".

"Errant graviter illi regis qui temere volunt subiectos, non amare;... proficit qui amat", Myrothecium Morale..., pág. 131. Cfr. CAstro, Agustin de, Conclusiones politicas del Príncipe, y sus virtudes... qüestión principal quién deua a quien más amor, el Principe a los vassallos, o los vassallos al Principe? Madrid, Imprenta Real, 1638.

23 "Sur le retour de François Duc de Guise après la prise de Calais, sous Henri II, en 1558" en Essai de traduction de quelques épitres et autres poésies latines de Michel de 1 ' Hopital. Chancelier de France, avec des éclaircissemens sur sa vie et son caractere. París, 1778, págs. 3738. No se ha podido cotejar esta traducción con el original latino de la carta.

24 Cfr. VERSNEL, H.S., Triumphus. An inquiry into the origin, development and meaning of the Roman triumph. Leiden, E.J. Brill, 1970. 
davão invençoens varias de festas. De todas as parte soavão instrumentos musicos" 25 .

Repárese en que estas líneas de Macedo las tomamos de un capítulo de su Eva e Ave que precede a la curiosísima transformación de la Asunción de la Virgen en auténtica joyeuse entrée en la Jerusalén Celeste, donde "os cidadoens celestiaes se vesterião de gosto" $y$ donde "tudo, finalmente, estava de festa" ${ }^{26}$. En ella, ingresa María tras haber atravesado las distintas esferas siderales convertidas en las estaciones que jalonan el recorrido triunfal de la nueva Reina del Cielo, precedida por ostentosos "carros de artificio glorioso" llenos de imágenes, en las que se mezclaban mitos clásicos (Dédalo, Faetonte, Hércules..., hasta Danae) con los más obvios emblemas y jeroglíficos de moralidad.

De la misma forma que el gran espectáculo cortesano se sublima en ese empireo materializado ${ }^{27}$, para la visión de la majestad real con todo su aparato de corte sólo parecerá buena la analogía de la contemplación celestial. Un testimonio excepcional nos lo proporciona fray Jerónimo de Sepúlveda, por mal nombre llamado El Tuerto, quien recordaba que, siendo apenas novicio en San Lorenzo de El Escorial, vio a Felipe II recorriendo los claustros del monasterio entre el cortejo de sus caballeros y que, entonces, pensó que aquello sólo podia ser “retrato del cielo" ${ }^{28}$.

Las Mémoires de Luis XIV insisten en que los efectos derivados de la "aparición del rey" a sus súbditos se obtienen, más que de la mera contemplación estática de su persona, de la participación ante y entre ellos, puesto que "tous nos sujets, en général, sont ravis de voir que nous aimons ce qu'ils aiment, ou à quoi ils réussissent le mieux» ${ }^{29}$. Más que otros ceremoniales cortesanos, es el espectáculo público de la fiesta el que entraña mayores posibilidades de "arrebatar» a los súbditos mostrándoles que el rey "ama lo que ellos aman". Por tanto, Luis XIV interviene activa y personalmente en festejos como el Carrousel de 1662; de la misma forma, Felipe IV había provocado el regocijo público al disfrazarse

25. MaCEdo, António de Sousa de, Eva e Ave ou Maria Triumphante. Theatro da erudiçāo, da philosophia chrystam. Em que se representam os dous estados do mundo. cahido em Eva elevantado em Ave. Lisboa, 1676, pág. 575.

26. Idem, id, pág. 579 .

Sobre la descripción de la vida «material» del cielo por los empireólogos barrocos, que trasladan todo el esplendor de la vida palaciega al firmamento, véase CARO BAROJA, Julio, Las formas complejas de la vida religiosa. Religión, sociedad y carácter en la España de los siglos xvi y xvm. Madrid, Sarpe, 1985, págs. 142-144.

28 Jerónimo de Sepulveda, Historia de varios sucesos. Madrid, ed. de J. Zarco, 1924, págs. 3-4.

^úmoires..., pág. 568. 
de máscara en febrero de 1623 solemnizando el carnaval madrileño, "con que se alegró el pueblo harto y mostró su Majestad la gallardía y brío que Dios le ha dado aventajándosse a los demás" ${ }^{30}$.

Si lo que buscaban los reyes al presentarse así ante sus súbditos era adueñarse del ánimo y corazón de éstos - «Par là nous tenons leur esprit et leur coeur...", dicen las Mémoires de Luis XIV ${ }^{31}$-, cabe preguntarse qué efecto surtía la pretendida seducción en quienes contemplaban estas regias salidas a escena. A falta, por razones obvias, de testimonios salidos directamente de esa misma muchedumbre que estaría compartiendo el espectáculo con sus reyes, para responder a esta cuestión quizá sólo podamos recurrir a la infinidad de autores que, durante los siglos $X V \mid$ y $X V I I$, insistirán en el asombro, la maravilla y la estupefacción que, a todos, les produce la regia visión ${ }^{32}$.

En el Diario Íntimo de Sören Kierkegaard encontramos un precioso pasaje que resulta extrañamente evocador tanto de lo barroco que podía llegar a ser su autor como del tipo de impresiones que provocaba la visión de los reyes. Pese a ser la suya una mirada desengañada que hace melancolía de los propios recuerdos infantiles, Kierkegaard parece haber captado el espíritu de lo que debieron ser los espectáculos cortesanos de la Edad Moderna y que él llegó a conocer, aunque fuera en su última expresión de comienzos del siglo xIx, cuando la aparición regia habia tomado la pátina de una tarde burguesa saboreada en un jardín con Kaffee-Haus.

En esta ocasión, el filósofo rememora el momento preciso en el que decidió hacerse escritor. Un domingo, hacia el verano de 1841, en el parque de Frederiksberg en Copenhague, lo invadió la melancolía al recordar que, siendo niño mucho tiempo atrás, había visto al rey Federico VI en ese mismo escenario:

«Pero ¿acaso existe algo que pueda sustituir la inolvidable impresión de la infancia: el rey es el rey y Federico $V$ l es el rey?.. $Y$ he aqui que... se presenta los domingos a bordo de un barco cuyo timón gobierna, con los remeros vistiendo su librea y rodeado de cisnes y de toda esa realidad que el niño conoce a través de sus juguetes de Núremberg y de sus propias invenciones; habia visto ya todo aquello: el rey y la reina bogando en una barca

30. El Conde Duque de Olivares al Cardenal de la Cueva. Madrid, 3 de febrero de 1623. Archivo de los Duques de Alba. Madrid, Caja 58.

Mémoires.... ed. de Ch. Dreyss, II, pág. 568.

Vid. nuestros "Retórica da imagem real. Portugal e a memória figurada de Filipe II", en Penélope. Fazer e desfazer História (Lisboa), 4 (1989), págs. 19-58; y "La majestad de Felipe II. Construcción del mito real», apud Martinez MiLlan, José (ed.), La corte de Felipe II. Madrid, Alianza, 1994, págs. 36-72. 
con el cortejo de los cisnes en pos de ellos. ¡Con cuánta fidelidad la imagen se ha precisado!... ¡Ah, sí: Federico VI, en sus paseos dominicales por el jardín de Frederiksberg, empuñando el timón y acompañado por sus remeros de librea y por el cortejo de los cisnes..., un mundo del pasado!» 33.

Hay aquí dos ideas que merece la pena destacar: la primera, la suposición de que la visión del rey no era más que la materialización de un recuerdo ya poseído con anterioridad; la segunda, la fuerza de una impresión visual que, pese a su fugacidad, se mantiene siempre en la memoria del espectador. Lo que así ha venido a definir este barroco Kierkegaard es, en el fondo, lo efímero, capaz, pese a su corta duración, de marcarse indeleblemente en el recuerdo porque traspone en concretas imágenes alegóricas las figuras retóricas ya acuñadas. El rey de ese niño que lo contempla lo es, y lo será siempre, porque su realidad se ajusta al rey que ya es en su imaginación; por unos breves instantes puede comprobar que realmente es como es.

Volviendo a los siglos XVI y XVII, cabría decir que los grandes espectáculos de corte respondian a idéntico mecanismo alegórico, que también ellos servían para re-conocer más que para conocer por vez primera la coherencia de un reino y de su íntima unidad. Toda una forma de entender la comunidad se expresaba por medio de la propia fiesta, cuyos protagonistas principales eran, de un lado, los mismos reyes, emblemas vivientes de la monarquía que representaban ante sus súbditos el papel de la majestad, y, de otro, la muchedumbre de espectadores, convertidos asimismo en emblemas vivientes del cuerpo de la monarquía. Lejos de oscuros jeroglíficos de intrincado significado, la fiesta moderna se debe a sí misma y se sume en su propio disfrute, en la urgente fruición del fuego, el agua, el ruido, el brillo, los olores y el color.

Su condición efímera era capaz de dejar un recuerdo indeleble en la memoria de los espectadores, puesto que las imágenes concretas en que se basaba, aunque se mantuviesen levantadas por muy poco tiempo, daban forma actual a ideas y tópicos ya conocidos, los cuales, por otra parte, no hacian más que reforzarse al haberse visto materializados de la manera más percusiva que quepa pensar. Sin embargo, dejando a un lado su propia apoteosis, la visión de lo efímero surtía buena parte de sus efectos porque contaba con un previo referente figurado que, canalizado por medio de los libros de emblemas, se vendría a reconocer gracias a su inclusión en el aparato de la fiesta.

39 Diario..., "1844. Hojas sueltas", pág. 116. 
A casi todas las imágenes que componían los arcos de las fiestas se les podría encontrar una fuente retórica expresada en forma emblemática, por excelencia en los Emblemata de Alciato. En suma, lo efímero de las imágenes de la fiesta, dejando a un lado el propio espectáculo que ya suponía la doble aparición regia y comunitaria, necesitaba el referente de otra forma de mirada que, en esta ocasión, se dirigiría hacia esos mismos símbolos pintados o, sobre todo, grabados. En este sentido, la mirada había empezado a exigir la lectura.

\section{LECTURA Y MIRADA. GÉNESIS DE LO EFIMERO MODERNO}

En el verano de 1523, Johann von Höfen, Johannes Dantiscus, legado del rey Segismundo I de Polonia en la Sajonia Ducal, escribía una reveladora carta a su amigo Piotr Tomicki en la que confesaba que se habia dejado vencer por la curiosidad al viajar desde Leipzig hasta Wittenberg con el objeto de ver a ese Martín Lutero del que todos hablaban. No era fácil que el antiguo agustino recibiera a un extraño, pero Dantiscus lo había logrado tras argumentar ante Melanchthon que "Quien en Roma no hubiera visto al Pontífice y en Wittenberg a Lutero, pensaria la gente que no había visto nada». En su carta, el diplomático ponderaba la agudeza, sabiduría y locuacidad que Lutero había mostrado durante la entrevista y, en suma, a la hora de exponerle a su corresponsal cómo era el reformador, Dantiscus se conformaba con apuntarle únicamente, como si no fuese necesario decirle nada más, que "Lutero tiene el rostro tal como aparece en los libros" ${ }^{34}$.

Además de recordarnos la íntima relación que la Reforma mantuvo con la imprenta desde sus momentos iniciales, así como que de su propaganda -ya lo observó António Sousa de Macedo en $1676{ }^{35}$ - no se excluian las imágenes, empezando por la de su protagonista principal, el testimonio de Johannes Dantiscus evoca una profunda transformación cultural que se produjo en Europa a partir del siglo xv. Como es bien sabido, la nueva doctrina luterana se estaba dando a conocer a todo el continente gracias a las prensas tipográficas, pero, además, los libros que de

\footnotetext{
Cito la epístola latina de Johannes Dantiscus a Petrus Tomicius, Cracovia, 8 de agosto de 1523, por la traducción de FONTAN, Antonio; y AXER, Jerzy (eds.), Españoles y polacos en la corte de Carlos V. Cartas del embajador Juan Dantisco. Madrid, Alianza Universidad, 1994, págs. 155156.

35 «... os Herejes pintão algumas dignidades Cathólicas em forma horrivel para enganarem os rusticos", Eva e Ave ou Maria Trivmphante..., pág. 479.
} 
ellas salian incesantes habían hecho que también fuera posible reconocer al propio Martín Lutero, ejemplificando, así, cómo la visión directa había pasado a establecer una nueva relación con la visión, valga la expresión, leída.

En términos generales, cabría decir que, durante la Edad Moderna, lo icónico-visual fue una forma de comunicación a la que se le concedía plena capacidad de significación y a la que, por tanto, se podía recurrir para percibir, expresar, conocer y recordar ${ }^{36}$. Sin embargo, debido a la disponibilidad y generalización de nuevas técnicas mecánicas de reproducción gráfica ${ }^{37}$, el mundo de las imágenes asistió a una profunda división en su seno. Fruto de ella fue que se pudo empezar a distinguir entre la tradicional visión directa y una nueva visión que se caracterizaba por ser diferida y que ya no era singular, sino difundida. Lo que es más, parece que se tuvo plena conciencia de que a una y a otra se les podía encomendar el cumplimiento de funciones distintas a tenor de la serie de específicas virtualidades propias de cada una de ellas.

Siglo y medio después de la visita del curioso Dantisco a ese Lutero que en realidad se "parecía" a sus retratos grabados, Diogo Henriques de Vilhegas publicó en Lisboa una serie de «direcciones acertadas para el govierno éthico, económico y político» que estaban dirigidas al Príncipe D. Pedro bajo el título de Leer sin libro. Aunque no se trata de una obra ilustrada, todo el conjunto discursivo descansa sobre la precisa equiparación de la lectura y la mirada:

«El leer es para percebir; el mirar una figura introduze en la misma inteligencia; con que sin libro vendré a conseguir advertencias para normas en la vida, para aciertos en el govierno, para obviar deslizes y tropieços, para introduzirme en plausibles aciertos" ${ }^{38}$.

En el «Exordio» que abre este Leer sin libro se explicaba el porqué de tan original título mediante una interesante, aunque sumaria, exposición de

\footnotetext{
3E Vid., por excelencia, el clásico de YATES, Frances A., The Art of Memory, London-Chicago, 1966

Cir. EISENSteIn, Elizabeth L., The Printing Press as an Agent of Change. Communication and Cultural Transformation in Early Modern Europe, 2 vols. New York, Cambridge University Press, 1979. Seguimos a la Profesora Eisenstein en lo referido a los efectos de la imprenta sobre la comunicación (difusión y fijación de los textos) y en su trasposición al campo de la imagen grabada.

38 VILHEGAS, Diogo Henriques de, Leer sin libro. Direcciones acertadas para el govierno éthico, económico y político. Dirigido al Señor Principe D. Pedro el Felice. Lisboa, António Craesbeeck de Mello, 1672, pág. 2.
} 
las distintas formas posibles de percepción y comunicación ${ }^{39}$. "Significar -empieza por argumentar Henriques de Vilhegas- es lo mismo que hazer conocer" y esto es algo que se puede conseguir "o por vozes, o por caracteres o por figuras". Sin embargo, las voces o palabras servirían sólo "para comunicar a los que assisten presentes los conceptos del ánimo", debiendo recurrirse a "los caracteres, letras o figuras" para "declarar a los ausentes nuestros designios, pensamientos y afectos: o para introduzirnos en el conocimiento del tercero" ${ }^{40}$. Por tanto, aunque la palabra, la escritura y la imagen se encuentran en pie de igualdad a la hora de significar "la cosa mesma y también el mesmo concepto" ${ }^{41}$, se establece, sin embargo, un particular reparto de funciones comunicativas en el que lo oral queda reducido a significar ante un auditorio presente, mientras que a lo escrito y a lo figurado se les atribuye la posibilidad de significar también ante los que están ausentes. Lo que resulta más sorprendente en esta exposición es que, contra lo que estamos habituados a encontrar, las imágenes visuales no se han alineado al lado de la oralidad, sino que han sido puestas al lado de la escritura, a la que casi vienen a reducirse unas figuras consideradas como caracteres. Cabría decir que el gran valor de la obra de Diogo Henriques de Vilhegas radica, precisamente, en que nos alerta sobre los efectos que la irrupción de la imprenta tuvo en la particular historia de las imágenes ${ }^{42}$. Esa mirada que permite significar ante los ausentes, venciendo, así, los imperativos de obligada presencia del espectador ante el objeto de su visión, es una mirada grabada y difundida en libros, en los cuales la visión ha unido su fortuna a la masiva mecánica reproductiva que es característica de las prensas tipográficas.

En la citada carta de Johannes Dantiscus también salía a relucir esta capacidad de significar ante los ausentes que se sabía era propia de las imágenes grabadas. Nunca antes había estado el embajador polaco en presencia del reformador, pero, sin embargo, él ya había visto a Martín Lutero, lo había visto... en los libros. Podía, además, garantizar a su corresponsal que la verdadera figura de aquel Pontífice de Wittenberg se ajustaba a ese retrato suyo difundido previamente y por el que ambos ya lo habían conocido.

Así, cuando se conformaba con decirle a Tomicki que "Lutero tiene el rostro tal como aparece en los libros", parecería que el dantisco, después

Cfr. Cur1o, Diogo Ramada, O discurso político em Portugal (1600-1650). Lisboa, Universidade Aberta, 1988.

Leer sin libro... pág. 1

Ibidem.

Ctr. HASKEIL, Francis, History and its Images. Art and the Interpretation of the Past. Yale University Press, 1993. 
de proceder a cotejar el original y su copia grabada, le estaba asegurando a su amigo que ningún error se había deslizado en el retrato que de Lutero circulaba, levantando una sui generis fe de erratas figurativa - similar a la que, con resultados menos favorables, hicieron Montaigne y sus compañeros al pasar por Ferrara y encontrar una efigie del Ariosto «un peu plus plein de visage qu'il n'est en ses livres» ${ }^{43}$. Y es que, además de hacer posible la difusión, la reproducción mecánica también estaba en condiciones de fijar la imagen que se entregaba a sus prensas -lo estaba en mucho mejores condiciones que el sistema de sucesivas copias manuales obtenidas a partir de un mismo original.

Por lo tanto, la Edad Moderna contó con un nuevo tipo de espectador cuya relación con el objeto de visión constituia una considerable novedad. La vinculación del grabado con los impresos permitió que las imágenes fuesen difundidas, es decir, que la visión no exigiese la presencia del espectador y, además, hizo posible que esas imágenes fuesen recuperables, pudiendo ser vistas cuantas veces se quisiera. Es evidente que cuadros o dibujos cumplian esta doble función con anterioridad y que, por supuesto, lo seguirían haciendo, pero, sin embargo, lo cierto es que, por su propia naturaleza, dibujos y cuadros lo hacian a una escala menor y limitada. Ahora, los nuevos espectadores de imágenes grabadas y difundidas en libros se enfrentaban todos ellos a las mismas imágenes -idénticas, o casi idénticas, entre sí- y su mirada era compartida en una proporción muchísimo mayor, haciendo posible el nacimiento de un especialísimo público de espectadores, cuyos integrantes se encontraban separados unos de otros, no se reconocían entre sí como tales, pero se hallaban todos ellos unidos por la visión de la misma imagen.

Las repercusiones derivadas de esta nueva mirada resultaron ser de la mayor importancia. De un lado, ayudaron a la estandarización y generalización de las imágenes, permitiendo tanto su definitiva codificación como la creación de auténticos repertorios visuales que, gracias a las nuevas condiciones de difusión seriada, pudieron llegar más fácilmente a las manos de un número también mayor de espectadores-lectores. De otro lado, la mecánica propia del proceso hacía posible que las informaciones confiadas a esta forma de difusión visual se perpetuasen y fuesen más fiables para quienes debieran emplearlas de una manera u otra. Así, tras la unión de imagen visual y libro impreso, por ejemplo, fue considerablemente más fácil

\footnotetext{
4.3 «Nous vismes en un eglise l'effigie de l'Arioste, un peu plus plein de visage qu'il n'est en ses livres"; cito por la edición bilingüe del Journal de voyage en Italie, par la Suisse et / Allemagne en 1580 et 1581. Madrid, Debate-CSIC, 1994, pág. 71.
} 
difundir una imagen y codificar un lenguaje de formas y esto tuvo enormes repercusiones que se extendieron desde lo arquitectónico a lo cartográfico, pasando por lo emblemático y lo político propagandístico.

Por último, esta nueva mirada leída también vino a repercutir tanto sobre la visión directa como sobre la contemplación de imágenes singulares (dibujo, pintura, escultura, arquitectura). Ni que decir tiene que una y otra siguieron cumpliendo plenamente las funciones propias de la comunicación icónico-visual, pero, además, se redifinieron con nuevos rasgos, haciéndose portadoras del valor añadido que entrañan lo restringido y lo irrepetible y que se derivaba, precisamente, de la existencia de aquellas otras imágenes, esas otras miradas leidas que se sabía eran iguales para todos y que se podían recuperar una y otra vez.

Sólo partiendo de la existencia de estas nuevas imágenes se puede calibrar exactamente lo que suponía y el valor que cabía atribuirle a una de esas grandes ceremonias de corte que se suelen englobar en la categoría de lo efímero. Cuando la imagen del rey podía ser difundida e, incluso, fijada o codificada, cuando podia ser conocida por quienes nunca liegarían a visitar la corte, pero que podían ver al rey y a su grandeza sin importar ni el lugar ni el momento, la continuada visión directa de los monarcas ganó la rara condición de privilegio, al tiempo que la extraordinaria aparición en público de los príncipes se convirtió en una ocasión dotada de una solemnidad y un aparato cuya excepcionalidad le debia mucho a la ordinaria visión que ofrecian libros y grabados.

Participar de forma destacada en los grandes espectáculos de corte era un medio de manifestar la calidad estamental, ya que el privilegio y la jerarquía se refrendaban en los puestos que se ocupaban en esas funciones reales, haciendo que surgieran constantes, e incluso virulentas, disputas porque se tributasen el rango y la preeminencia que eran debidos. No hay que olvidar que la fiesta efímera estaba sometida a la etiqueta y que, aunque en ella todo pareciera bullicio y alegre improvisación, el imperio del protocolo era absoluto, precisándose mucho tiempo, además, para organizar los recorridos y las comitivas, levantar los arcos triunfales o disponer los diferentes juegos y demás diversiones que solían acompañar estos grandes fastos.

Asi, en los Note Books de John Finet, Master of Ceremonies de Carlos I de Inglaterra, se deja constancia de cómo, con motivo de la boda entre la Princesa María y Guillermo de Orange en 1641 , no se pudo lograr «the solemnity and feast to be carryed in publick" porque:

"...the preparative must be answearable, solemne invitations made of ambassadors to it, as then, severall tables kept in court, the king and the queen 
to be served by themselves, masks and showes in time to be prepared and set forth, which would require a months time and more" ${ }^{44}$.

Varios meses, y muchos gastos, eran precisos para que el efímero festivo se produjera, siendo indispensable para su preparación el poder contar con la memoria de lo ya hecho en ocasiones anteriores. En la Real Biblioteca de Madrid se conserva un ejemplo excepcional que demuestra lo poco que se dejaba al azar en estas grandes ceremonias; se trata de la colección de trazas, plantas y repartimientos de puestos para un buen número de las ceremonias regias que tuvieron lugar en Madrid a lo largo del siglo XVII y que fue mandada hacer por el Marqués de Eliche en 1660 con vistas a la organización de nuevas funciones reales a su cargo. Este soberbio, a la par que útil, taccuino festivo fue continuado por los sucesores de Eliche hasta llegar al año $1704^{45}$.

Extraordinaria circunstancia era ésta en la que la majestad regia se daba en espectáculo al reino, pero también en la que los amigos del monarca, sus elegidos, podían mostrar lo cerca que estaban del rey. Y, además, el efímero mirar de los grandes espectáculos de corte, con su orden jerárquico y el reconocimiento de la amistad de los validos, solía ser transformado en mirada-lectura cuando se confiaba a la imprenta la relación de los festejos y al grabado la difusión de su magnificencia ${ }^{46}$.

Por supuesto, aquel carrousel que motivó las precisas "Réflexions" que Luis XIV le hacía al Delfín pasó a las prensas y apareció bajo el título de Courses de testes et de bagues faites par le roy et par les princes et seigneurs de la Cour, en l'année 1662, como también lo hicieron Les plaisirs de l'isle enchantée de 1664, que asimismo contaron con la participación real, y otros divertissements de la corte parisina y versallesca ${ }^{47}$. Así, lo efímero de la fiesta se convierte definitivamente en propaganda, fi-

LoOmie, A.J. (ed.), Ceremonies of Charles l..., op. cit., pág. 312.

Plantas orijinales que se an executado en esta corte en proçessiones del corpus y auto general de la fee en que su magestad asistió, RB, 1//1066 bis.

45 Cfr. MAII.LARD, Jean-François, «De la maquette autographe à l'imprimé: La somptueuse et magnifique entrée du roi Henri lll à Mantoue par Blaise de Vigenère (1576)" apud MARTIN, H.J.; y Dupuigrenet Desrousilles, F., Le livre dans l'Europe de la Renaissance. Paris, Promodis, 1988, págs. $71-84$.

Ambas obras aparecieron en la Imprimerie Royale de Paris, la primera en 1670 y la segunda en 1673. Vid. POGNON, E., "Une nouvelle séduction. Les livres de fêtes et la propagande officiele", en L'art du livre à l'Imprimerie Nationale. París, Impremerie Nationale, 1973, págs. 143161. Cír. Mathla Roofiguez, José Manuel, "Grabado y propaganda. La imagen de los palacios reales en la Europa moderna", apud CHECA, Fernando (ed.). El Real Alcázar de Madrid. Dos siglos de arquitectura y coleccionismo en la corte de los reyes de España. Madrid. Comunidad de Madrid-Nerea, 1994, págs. 460-485. 
jando y difundiendo las imágenes de esa "société douce et honnête" que se complacía en verse a sí misma, ordenada y brillante, en ardiente agitación.

En sus Errores celebrados, Juan de Zabaleta escribía que la sola presencia de los reyes despertaba el amor de sus vasallos, pero que, siendo imposible que todos entraran en corte para verlos, debían los monarcas buscar los medios para hacer llegar su imagen, sustituta de su presencia, hasta sus súbditos.

“¿Con qué pagaría - pregunta Zabaleta - un rey un hechizo con el cual, sin caer en culpa, se pudiera hacer a un mismo tiempo presente en todos sus estados donde, causando alegría, se granjeara amor y respeto? No era caro en la mitad de su corona» ${ }^{48}$.

El mismo autor nos da la respuesta: «Este hechizo son los retratos y las estatuas, malos o buenos, y no tienen costa" ${ }^{49}$.

\section{EPÍLOGO. EL CETRO EN EL PINCEL}

En el siglo XVII, se tuvo plena conciencia de la enorme utilidad que tenía lo visual para el incremento del poder de los príncipes - piénsese en lo que se dice a este respecto en las "Réflexions du Carrousel» de Luis XIV o en el impagable hechizo de "enamorar» súbditos a distancia de Zabaleta. Ese rey que quiere, si hemos de recurrir a las mismas categorías que aquel siglo, despertar el amor en su reino se encuentra con las artes visuales como instrumento especialísimo. De un lado, porque le permiten difundir y fijar su imagen, ante todo en su forma grabada; de otro, porque era mucho lo que teóricamente se esperaba del arte visual para incitar a sentir ese amor.

A la clásica polémica renacentista del paragone entre los retratos poéticos y los pintados - ¿quién será más afortunado en la representación de la belleza de la persona amada, el poeta o el pintor? ${ }^{50}$ - Frei António Lopes Cabral le añadió unas cuantas pinceladas barrocas de valiente

te Zabaleta, Juan de. Errores celebrados, ed. de David Hershberg. Madrid, Espasa-Calpe, 1972, pág. 56.

It. Ibidem.

5i. Vid. DEMPSEY, Charles. The Portrayal of Love. Botticelli's Primavera and Humanist Culture at the Time of Lorenzo the Magnificent. Princeton. Princeton University Press, 1992. págs. 146150 . 
color. Quiso este académico dos Singulares no ya encomiar la capacidad pictórica para expresar la idea amorosa ${ }^{51}$, sino transformar al amor en un consumado maestro de la pintura, reservándole al odio, en su particular economia sentimental de las bellas artes, el seco oficio de escultor. En el prólogo "A quem ler" que abre su Pancarpia, publicada en Lisboa en 1694, se afirma que:

"O amor pinta, e como quer o que pinta, pinta como quer» ${ }^{52}$.

Semejante elogio de la pintura no desdice de ese otro que aparece en un sermón predicado por el mismo Cabral la fiesta de san Lucas de 1678 en la Anunciada lisboeta ante los pintores de la corte. En aquella ocasión, los instrumentos propios del arte pictórico fueron elevados a la categoría de las insignias reales. "Quantas vezes - asegura - se virão em as mãos reaes equivocados os ceptros com os pinceis, as púrpuras com as tintas, e os báculos com os tentos? ${ }^{53}$.

Aunque es posible que, con estas palabras, Lopes Cabral no pretendiera otra cosa que lisonjear a su auditorio, se entiende que bien dispuesto a oir hablar de equivocaciones que les resultaban tan favorables, la forma que tiene de vincular lo regio y lo pictórico resulta extraordinariamente evocadora de la íntima, y mutuamente benéfica, relación establecida entre el poder monárquico y las artes visuales a lo largo de la Edad Moderna.

51 Vid. Cropper, Elizabeth, "The Beauty of Woman: Problems in the Rhetoric of Renaissance Portraiture", apud FERGuson, Margaret W., Quil.LIGAN, Maureen, y VICKERS, Nancy J. (eds.), Rewriting the Renaissance. The Discourses of Sexual Difterence in Early Modern Europe. ChicagoLondon, The Chicago University Press, 1986, págs. 175-190, 355-359.

Pancarpia ou capella florida. Lisboa, 1694, "A quem ler".

53 Ídem, pág. 364. "Sermāo XVII. Os Retratos. Pregado na festa de S. Lucas evangelista no Convento da Annunciada de Lisboa, com o Senhor exposto, na solemnidade que the dedicarāo os Pintores desta Corte". 